An International Multidisciplinary Journal, Ethiopia

Vol. 7 (3), Serial No. 30, July, 2013:340-352

ISSN 1994-9057 (Print)

ISSN 2070--0083 (Online)

DOI: http://dx.doi.org/10.4314/afrrev.v7i3.24

\title{
Responses to the 1983 Expulsion of Aliens from Nigeria: A Critique
}

Aremu, Johnson Olaosebikan - Department of History and International Studies, Ekiti State University, Ado- Ekiti, P.M.B. 5363, AdoEkiti, Nigeria

E-mail: johnsonaremu2006@yahoo.com

嬖+2348032477652

\begin{abstract}
The Nigerian Government expelled over two million illegal aliens from her territory on 17 January, 1983 for social and economic reasons, majority of whom were West Africans mostly from Ghana. However, her action was greeted with a barrage of criticism by members of the international community at large. This paper attempts a critique of this plethora of criticisms and submits that the Nigerian government of Shehu Shagari acted in conformity with the Nigerian immigration law of 1963 as informed by the exigencies of national interest. Government should therefore be exonerated from all the said criticisms.
\end{abstract}

Key Words: Expulsion, Aliens, Criticisms, Nigeria, Exodus

\section{Introduction}

On 17January 1983, Alhaji Ali Baba, the then Nigerian Federal Minister of Internal Affairs, in a television broadcast, ordered all unskilled foreigners residing and working illegally to leave the country by 31 January 1983 . For 
the skilled aliens, they were allowed to stay up to 28 February 1983. The Minister added that from 31 January 1983, security agents would inspect commercial and industrial establishments, as well as households, to identify defaulting aliens, and that those found contravening the order would be repatriated and their names put on a stop list to ensure that they did not return to Nigeria. It was further announced that registration of legal aliens would begin on 14 February 1983 at the immigration headquarters in all the 19 states and Abuja. The Minister warned that "all companies found to be illegally employing aliens would be severely dealt with under the immigration laws." 118 Employees of federal, state, and parastatals as well as citizens of Cameroon and Chad who had come to Nigeria before 1963, were however excluded from the expulsion order "irrespective of what they do".

Some of the major reasons cited by the Nigerian government for the expulsion of illegal aliens by Nigeria in January, 1983 included: ensuring the integrity of Nigerian immigration laws; the general economic recession which resulted in the reduction of foreign exchange earnings to Nigeria since 1981; the involvement of some foreign nationals from neighbouring countries in violent religious disturbances in Nigeria and; involvement of some Ghanaians in some crimes, including armed robbery in Nigeria. But apart from these official reasons cited by government, a reasonable implied rationale for the 1983 expulsion order was probably the growing frustration among Nigerian policy-makers as to the failure of ECOWAS to adequately serve Nigeria's national interest of projecting her leadership ambition in the West African sub-region.

A lot of criticisms were however levied against Nigeria's action of expelling illegal aliens from Nigeria in 1983. In the first instance, critics argue that the expulsion order was too sudden. Though most critics did not dispute Nigeria's sovereign right to enforce the relevant ECOWAS protocol and its immigration laws, they argued, however, that the expulsion came too sudden. Given the provision of the ECOWAS Protocol on Free Movement of Persons which stipulates that where ECOWAS citizens are to be expelled or deported, such decision to expel should be communicated to the citizen, his government, and the executive secretary of the organization (Chhangani, 1983), critics have accused the Nigerian government of arbitrariness in the issuance and enforcement of the 1983 expulsion order. It was largely insinuated that major departments of the Nigerian Government were left unaware of the Order. The Ministry of External Affairs first heard about it on television. The Department of Immigration, which was about to introduce 
a new aliens registration scheme, was similarly left out of the picture.(Africa Now, February 1983:47) The Police Force, which would surely have a major role to play in such a massive undertaking, came across it in the newspapers and 'almost one week after the go home order on illegal aliens resident in Nigeria the Police (were) yet to receive a directive from the Federal Government on enforcement'.(Sunday Punch (Nigeria) 23 January 1983) It was further claimed that Nigeria's embassies and high commissions abroad received no official notification and were similarly reduced to gleaning what they could from the media, in spite of a large retinue of image makers called different names. There are information men, press secretaries, special advisers on information, special assistants on information, liaison officers, directors and general managers of government-controlled media, public relations men in government agencies and parastatals and a number of mediarelated appointees; besides the Federal Government controls a large amount of both electronic and print media in Nigeria and, above all, there is a Minister in charge of Information.(West Africa, 2 May 1983.) In spite of this communications arsenal, it was argued, "the issuing of the Aliens Order could unwittingly qualify as the year's best kept secret" (Gravil, 1985:527).

On the contrary however, the Nigerian authorities maintain that the governments of member states of ECOWAS were duly informed about the decision to expel illegal aliens. (Adepoju, 1984: 432) O.O. Fafowora (1983:391), then Nigeria's Ambassador to the United Nations, on 4 February 1983 through a press statement was indeed quick to counter the insinuations and declared that contrary to what the press would have the public believe, the Federal Government's order was in no way precipitate and was made only after due consultations with the governments of member states of ECOWAS [Economic Community of West African States]. Those governments were kept fully informed in advance of the decision of the Federal Government that, for a variety of legitimate reasons, Nigeria could no longer continue to harbour unskilled illegal immigrants. All the governments concerned agreed with the view of the Federal Government of Nigeria that the expulsion order did not in any way contravene ECOWAS' protocols on the free movement of people and goods within the Community. This is why there has been no protest from any of the governments concerned. He added that "we know from our contacts with those governments that they fully understand the circumstances in which the order had to be made. It was generally recognized that the Government had to act when it did. The presence illegally in Nigeria of such a large number of immigrants had serious economic and security 
implications which had to be carefully considered by the Government, particularly in view of the persistent domestic pressure on the Government to act. Social services were stretched to the limit, thus imposing an intolerable strain on the social fabric of the nation" (Ibid).

Critics also claimed that the Federal Ministry of External Affairs was not involved in the expulsion order. They suggest that the senior staff in the Ministry of External Affairs first heard of the decision taken by Ali Baba on the day that it was announced and that they were particularly frustrated by the expulsion order, not least because thousands of Nigerians were residing in other West African countries. Though the Minister of External Affairs, Ishaya Audu, refuted the claim, the fact cannot be denied that, the President, Alhaji Shehu Shagsri gave an executive approval to the expulsion order, while the Federal Executive Council as a statutory body did not ratify the decision until I8 January,1983, two days after the public announcement by the Minister of Internal Affairs (Brown, 1989:271).

But whatever procedural error(s) that might have been committed by Ali Baba may be excused on the altar of exigencies of national interest. As Olajide Aluko rightly submits, as devout Muslims, both Shagari and Alhaji Ali Baba had not only an appreciation for law and order, but also a distinct distaste for 'loose living' which probably explains the near spontaneity of their action (Aluko, 1985: 541). Aluko adds further that the Minister's almost exclusively business-oriented background and lack of intimacy with the intricacies of inter-state relations may explain his apparent lack of an appreciation of the interconnectivity of internal policies of states and the international perspective. (Ibid: 42). Certainly Ali Baba could not have realised what would be the external implications of the serious error of judgment represented by the expulsion order. Neither he nor his officials in the Ministry of Internal Affairs seemed to have any realistic notion of either the number of aliens affected by the order, or how and when they would actually leave, let alone the diplomatic ramifications of their enforced departure.

Finally, N.O. Addo adds that the suddenness of expulsion orders is not a new development when he noted that "In the Nigerian, as in other cases in Africa, the events leading to the expulsion of aliens have been gradual but in all cases, the actual expulsion or decisions to expel are usually sudden and dramatic" (Addo, 1982:31-38.) thereby exonerating the Nigerian government from any misdeed. To ease whatever trauma deportees might be going 
through then; Fafowora (1983:392) declared further that "the Federal Government of Nigeria as well as all relief agencies in Nigeria is cooperating fully with the United Nations Secretariat in facilitating U.N. and other relief assistance to those being evacuated" (ibid).

Critics have also raised a moral question on the timing of the Nigerian expulsion of illegal aliens in January 1983 with particular reference to the parlous state of Ghanaian economy since 1981. During this period in question, the Ghanaian economy was faced with acute challenges and may even be said to be in a state of total collapse. Kofi Awoonor's summary of the state of Ghana's economy during the period captures the picture vividly. According to him,

the factories were operating around $20 \%$ capacity, crippled by inadequate spare parts supply and raw materials. The little that was produced was absorbed into the officially sponsored profiteering network. The black market boomed and there was speculation in cloth, cement, fish, iron rods, soap, matches, sugar and other so-called essential commodities. Because the cedi remained fixed at 2.75 to the U.S. dollar, the exporter had no incentive to export as his production cost and other expenses wiped-out any profits. Inflation rose to $116.5 \%$ and the value of worker's wages fell to $20 \%$ of its value in 1970 . The negative industrial growth rate reached as high as $30 \%$ while the transport sector virtually collapsed in the face of inadequate spare parts and inability to import new vehicles. Railway freight which registered 1,137,000 tons in 1976 stood at 566,000 in 1981. In terms of prices, a bottle of palm-oil rose from 0.39 cedis in 1979 to $£ 41.30$ in 1981 and gari 0.24 cedis a pan in 1976 to c14.35 (Awoonor, 1990:245-246).

During the same period, Oquaye (2004:100) also reports that allegations of bribery, corruption, inflation and profiteering gripped Ghanaians as workers' protests escalated. Rumours of contractors doing shoddy jobs and pocketing contract monies were equally rife. Armed robbery and other criminal activities thrived in the period too. The period also witnessed a phenomenal hike in Ghana's external debts from c6billion to c15.5billion between 1980 and 1982 (Bukari, 1982). 
Such an economic mal-administration could not but attract strikes and protests by the workers' union. One of such was the June 1980 invasion and occupation of Parliament House, Accra by workers of the Ghana Industrial Holding Corporation (Ibid). Apart from disrupting the work of the House, the protesters also ate the food prepared at the kitchen for Members of Parliament (MPs); destroyed property belonging to the State, and warned the MPS against indulgence in corrupt practices to avoid bloodshed (Oquaye, 2004:451). In a nutshell, the Ghanaian economy as at early 1982 was characterized by budgetary deficits, declining real output, hyper-inflation, smuggling and corruption. There was a drastic decline in production of all goods and commodities (Ibid).

Expulsion was also seen as an attempt to divert the attention of Nigerians from the economic woes of the country and the corruption charges against Shagari's government. For instance, The Ghanaian Times described the expulsion ultimatum as "pregnant with ulterior motives." The paper stated that the re-election campaign of the ruling National Party of Nigeria (NPN), was "in serious disarray" and that the expulsion order was a diversion to save the waning image of the Party among Nigerians so that it could win the 1983 elections. It therefore concluded that "this unacceptable use of the Ghanaians' presence was a face-saving gimmick". ${ }^{351}$ Similarly, some western analysts claimed that Shehu Shagari, the Nigerian President, wished to capitalise on the widespread resentment against Ghanaians in Nigeria in order to gain political points in an election year, and that the National Party of Nigeria (N.P.N.) wanted to demonstrate its ability to act decisively in coping with the nation's overall economic problems(Afolayan,1988:18). The Economist (5 February 1983:I3) also described the expulsion as the "Nigerian president's xenophobic way of courting votes in next summer's election at a time when his country's economy is in well-deserved tatters." Lastly, in the view of Louis (1983:12) the Nigerian leader only tried to use the two million Ghanaians as scapegoats to divert attention from the economic crises and the corruption charges that could hurt him in the balloting.

A question mark has also been put on the moral mission of the Nigerian government to curb the preponderance of social menace and religious conflicts by expelling the alien population. For instance, Royal Gravil argues: if the first in the series of the religious disturbances cited by government occurred as long as December, 1980, with another round taking place in September, 1981, as a commemoration of the death of the Cameroonian fanatic, Muhammed Marwa alias Maitasine; and if truly the Panel of Inquiry 
set up by government was sure of its findings which implicated illegal aliens in the rioting, why did it take the Nigerian government authorities another two years to implement the recommendations of the Panel? Another salient question asked by Roger Gravil is why expelling Ghanaians when all but a score of Maitasine's alien followers came from Niger Republic with even none from Ghana? Thirdly, Gravil asks, "why deport two million Christians in a measure aimed a ridding Nigeria of Islamic militants and fundamentalists?" (Gravil, 1985:535). Roger Gravil was totally right in posing such questions as raised above. However, he need be reminded that the expulsion order was never directed at nationals of a particular country. Rather, it was meant to purge the country of all illegal aliens, not minding their nationalities. In fact, designating which alien nationals are to be expelled would not only have created a problem of implementation due to the fact that none of them carries unique mark or papers of identification; it would also have amounted to xenophobia against such designated nationals. Government may therefore be said to have done its best by expelling all illegal aliens. In such situations, adherents of any religion whatsoever could have been affected once they are illegal aliens just as it happened in the 1983 expulsion.

Nigeria's decision to expel illegal aliens in January 1983 also created an international crisis for the country. The decision was not just widely criticized, but was also strongly condemned by many countries of the world. As a matter of fact, it created a near-universal and unexpected hostility towards Nigeria. For example, the United States of America through the U.S. State Department in Washington described the decision as "shocking" and claimed that it represented a violation of "every imaginable human right". (National Concord (Lagos) 8 February, 1983; (Brown, 1989:254-255 \& Aluko,1985:423) The European Economic Community (EEC) in a press statement in Brussels deplored the expulsion order and its mode of implementation.( Sunday Concord (Lagos), 13 February, 1983) The expulsion was also described as "an act of heartlessness and a failure of common humanity" by Mr. Michael Foot, the opposition leader in the British House of Commons.(National Concord (Lagos), 8, February, 1983) In its own opinion, the French press described it as "an act of barbarism unparalleled in the world" (Aluko,1985: 424). In a similar vein, Pope John Paul II also described the expulsion of illegal aliens from Nigeria as "a grave, incredible drama" producing the largest single and worst human exodus in the century" (Sunday Concord, 13 February, 1983) The Heads of States of 
Cote d'Ivoire, Benin Republic, Burkina Faso, Niger and Togo also issued a joint statement condemning Nigeria's expulsion of illegal immigrants in 1983. The act was denounced as "contrary to the spirit of African hospitality and various international agreements" (Afolayan, 1988:18-19; African Economic Digest, 1983:6726). In all, the 1983 expulsion soiled NigeriaGhana diplomatic relations.

It need be observed, however, that the above sampled comments in reaction to the 1983 expulsion of illegal aliens by Nigeria were rather outrageous. It appears that other nations of the world, for reasons best known to them, were in a mere gang-up against Nigeria. This observation is based on a number of salient facts. In the first instance, precedents existed in West Africa for designating foreigners as scapegoats for various socio-economic and political woes. In 1958, Ivory Coast and Chad in separate acts expelled Beninese and Togolese numbering over 1000 designated as illegal migrants by both countries. Ivory Coast repeated the same feat in 1964 by expelling another set of 16,000 Beninese. In 1967, it was the turn of Senegal to expel a sizeable number of Guineans for entering the country illegally. In 1978, Gabon expelled Benin nationals in retaliation for a Beninese condemnation of Gabon at an O.A.U meeting. Furthermore in 1979, Ghana and Ivory Coast also expelled Togolese farmers from their countries ( The Nigerian Observer, 28, July, 1973:3; Yaro, (n.d) cited Adepoju,2005:12; Coles, 1983:27-31, 3336; New York Times, 3 May 1985.) Indeed, Nigerian nationals had previously been expelled from several African countries including Gabon, Equatorial Guinea, Sierra Leone, Cameroon, Ivory Coast and most notably, from Ghana, between 1964 and 1969 ( Nigerian Observer, 28 July, 1973:3). It should be recalled that in 1969, the Ghanaian government headed by Kofi Busia expelled about 150,000 Nigerian migrants and other aliens totaling about 500,000 in number from other neighbouring countries for not possessing legal residence permits. In 1973 more Nigerians were also ejected forcefully when a new Ghana Investment Policy Decree came into effect (Daily Times, 4 February, 1969).

Judging from the above catalogue of cases of expulsions in Africa before, one wonders why other countries of the world cried foul at Nigeria's action of expelling illegal aliens in January 1983. Nigeria's case was definitely not the first and may probably not be the last. Then, if others had a right to expel and deport illegal aliens, ostensibly for economic and political reasons without international challenge, what makes the Nigerian case so special that every dick and harry had to blame Nigeria. If anybody would cry foul 
regarding the short notice and the harshness of implementation in the 1983 Nigerian case, such people may need to be reminded that the 1969 Aliens Compliance Order in Ghana was applied with a worse harshness. Let critics be informed that Nigeria has a right to determine what her national interests are at any point in time and should be free to take necessary steps in that direction.

With respect to the stampede and some hardships experienced by expelled foreigners on their way back home from Nigeria, critics should note that such hardships were not intended. As a matter of fact, necessary care was taken by the Federal Government of Nigeria, including the provision of transportation, to ensure the safety and orderly evacuation of the illegal aliens affected by the 17 January 1983 order. As a matter of fact, it was glaring that the initial confusion and panic would have been avoided if the borders of the receiving countries had been opened on time. The delay in opening the Benin, Togo and Ghanaian borders contributed immensely to the hardships which the expelled migrants were exposed to.

\section{Negative Impact of the expulsion}

On the negative impact that the expulsion may have on the role of Nigeria in the process of forging regional economic cooperation, in West Africa, nobody would ever be able to deny the enviable role played and being played by Nigeria in this direction. Before 17 January 1983, the Nigerian government's commitment to ECOWAS was not in question. Right from the efforts of Yakubu Gowon, in collaboration with Gnassingbe Eyadema of Togo, that led to the formation of ECOWAS in 1975 even till the era of Shehu Shagari when the protocol on free movement of people across West Africa was adopted in 1980; Nigeria's initiative at forging a united and economically viable West African sub-region has never been in question. As Leann Brown reports, in an address to the Heads of State in Lome, Togo in May 1980, President Shehu Shagari of Nigeria reiterated the commitment of his administration and the country at large to the success of the ECOWAS protocols and Treaty. According to him:

"I ... wish to assure you, Mr. Chairman, that my administration is fully committed to the Economic Community of West African States. We shall continue to give sure support to the Community in the realisation of its goals and objectives" ( Tijani and Williams, 1981:202203). 
Given Nigeria's ever-ready support for ECOWAS, Shagari's expulsion of illegal aliens in January 1983 should have been clearly interpreted in terms of national exigencies, rather than blindly condemning the act. Following from the various newspaper reports and the report of the panel of inquiry into the religious riots at Kano, Kaduna and Maiduguri between 1980 and 1982 in which aliens were strongly indicted, it was clear that some of the illegal aliens have constituted themselves into social liabilities to the country. If care was not taken by government, the security of the country would no doubt be seriously threatened in view of the huge number of such unregistered aliens scattered across the country. What Nigeria did in expelling the illegal aliens as a way out of the socio-political ills that confronted the country then may thus be regarded as doing what was right and not necessarily what was good in line with the Machiavellian principle of amorality of the state.

However, there is a limit to the tenability of this moral argument for Nigeria's expulsion of illegal aliens in 1983 going by some salient questions that may be raised concerning the long term effect of the expulsion on Nigeria's socio-economic life. Since, the aliens were expelled about thirty years ago, has there been any significant improvement in Nigeria's economic fortunes? Has the challenge of unemployment been successfully tackled by the government? How many new job outlets has the government been able to generate since the exit of the aliens who were accused of taking up jobs meant for Nigerians? How far has Nigeria been able to expand the production capacity of her industries? What significant step is government taking to resuscitate the collapsed industries? Has there been any drastic reduction in poverty level of Nigerians after the exit of the illegal aliens? These and numerous other related questions need be addressed positively. These calls for a national rethink on the appropriate strategy for arresting unemployment and poverty in Nigeria. We should look inwards henceforth for solutions to our economic woes rather than blaming foreigners.

The increasing crime rate, as well as the incessant religious and ethnic crises in Nigeria in the post-expulsion era, also lends credence to the view that aliens may not necessarily be blamed for such calamities in Nigeria. Government should therefore devise viable and concrete security measures and strategies for the country rather than beating about the bush by castigating aliens for offences which they probably knew nothing about.

The expulsion order of 17 January 1983 also raises the question of the scourge of corruption in the Nigerian society. If truly the expelled aliens 
entered the country illegally as claimed by the Nigerian government, then the question that readily comes to mind is: where were the immigration officials when such a large number of aliens entered the country? Could it be that they were all sleeping when these aliens crawled across the border at night? Or were the officials on strike then which made them to leave their border posts? Definitely, an average Nigerian is aware of the fact that these immigration officers were not sleeping, and neither were they on strike. Some may thus be quick to explain that the officers were incompetent and that the Nigerian international borders and boundaries are too long, un-policed and porous for effective boarder control. However, it is glaring that corruption among immigration officials supersedes all other possible factors for the porous nature of our borders. Government must therefore venture into formulating and implementing policies aimed at curbing the rampant scourge of corruption in all facets of the Nigerian economy.

\section{Conclusion}

All said and done, the 1983 expulsion of illegal aliens by the Nigerian government was not an illegality at all. It was done in conformity with relevant sections of the Nigerian Immigration Laws of 1963. Though the act had serious implications for Nigeria's role as a core-state on whom the success of ECOWAS largely depended, the fact remains that as a sovereign state, the Nigerian government had a right to determine what policies best serve her national interest without consultation with any foreign government. Similarly, if other countries have expelled aliens from their territories without much cry, all the foul cries against the Nigerian action in 1983 may best be regarded as mere hypocrisy by the international community against Nigeria.

\section{References}

Addo, N.O. (1982). "Government Induced Transfer of Foreign Nationals" in Clarke J.I. and Kosinski, L.A. (eds.) Redistribution of Population in Africa (London: Heinmann,1982).

Adepoju, A.(2005). "Migration in West Africa", a paper prepared for the Policy Analysis and Research Programme of the Global Commission on International Migration.

Adepoju, A. (1984). "Illegals and Expulsion in Africa: The Nigerian Experience", International Migration Review, Vol.18, No.3. 
Afolayan, A.A. (1988). "Immigration and Expulsion of ECOWAS Aliens in Nigeria”, International Migration Review, Vol. 22, No. 1 (Spring).

Africa Now, February 1983.

African Economic Digest, 1983.

African Research Bulletin, 1971.

Aluko, Olajide (1990). "The Expulsion of Illegal Aliens from Nigeria: A Study in Nigeria's Decision-Making, in G. O. Olusanya and R. A. Akindele (eds.), The structure and processes of Foreign Policy Making and Implementation in Nigeria, 1960-1990, (Lagos: NIIA)

Awoonor, K. (1990). Ghana: A Political History (Accra: Sedco Publishing Ltd and Woeli Publishing Services).

Brown, M. Leann, (1989). "Nigeria and the Ecowas Protocol on Free Movement and Residence", The Journal of Modern African Studies, Vol. 27, No. 2 (Jun., 1989)

Chhangani, R.C. (1983). "Legal Status of ECOWAS Citizens" Nigerian Forum, Nigerian Institute of International Affairs, Lagos.

Coles, G.J.L.,(1983). “The problem of mass expulsion”, Background Paper for Working Group of Experts on the Problem of Mass Expulsion, Convened by the International Institute of Humanitarian Law, San Remo, Italy, 16-18 April.

Daily Times, 4 February, 1969.

Dowty, Alan (1986). "Emigration and Expulsion in the Third World", Third World Quarterly, Vol.8, No.1, (January)

Fafowora O.O, (1983). "On the Expulsion of Illegal Migrants from Nigeria Population and Development Review, Vol. 9, No. 2.

Federal Government of Nigeria, (1963). Official Gazette Extraordinary, Supplement, No.4, Vol. 50, June.

Gravil, R, (1985). "The Nigerian Aliens Expulsion Order of 1983" African Affairs, Vol. 84, No. 337 (Oct).

Ihonvbere, J. O. (1991). "Nigeria as Africa's Great Power: Constraints and Prospects for the 1990s", International Journal, Vol. 46, No. 3, 
Regional Powers (Summer)

Louis,E.T., (1983). “West African Tragedy”, Politics, Tuesday, 8 February.

National Concord (Lagos). 1983.

New York Times, 3 May 1985.

Okolo, J. E., (1984). "Free Movement of Persons in ECOWAS and Nigeria's Expulsion of Illegal Aliens", The World Today, Vo 1. 40, No. 10.

Oquaye, M.,(2004) Politics in Ghana, 1982-1992: Rawlings, Revolution and the Populist Democracy (Accra: Tornado Publications)

Sunday Concord (Lagos). 13 February, 1983.

Sunday Punch (Nigeria) 23 January 1983.

Sunday Times (Lagos), 1983

The Economist, 1983.

The Nigerian Observer, 28, July, 1973.

Tijani, Aminu \& David Williams (eds), (1981). Shehu Shagari: My Vision of Nigeria, (London)

West Africa, (London), I983.

West Africa, 2 May 1983.

Yaro, J. A., Migration in West Africa: Patterns, Issues and Challenges, (Centre for Migration Studies, University of Ghana, Legon (n.d). 